\title{
The Influence of International Pre-Service Teaching Program towards Students' Speaking Ability at Muhammadiyah University of Makassar
}

\author{
Suardi ${ }^{1}$, Erwin Akib ${ }^{2}$, Amar Ma'ruf ${ }^{3}$ \\ ${ }^{1}$ English Education Department, Faculty of Teacher Training and Education, Muhammadiyah \\ University of Makassar, Indonesia
}

\begin{tabular}{|c|c|}
\hline Artic & Abstract \\
\hline $\begin{array}{l}\text { Article history: } \\
\text { Received: } 07 \text { July } 2020\end{array}$ & $\begin{array}{l}\text { Purpose: The aim of this research study is to measure the influence of } \\
\text { International Pre-service Teaching Program on students' speaking English } \\
\text { ability at Muhammadivah Universitv Makassar. Indonesia. }\end{array}$ \\
\hline $\begin{array}{l}\text { Revised: } 26 \text { August } 2020 \\
\text { Accepted: } 27 \text { August } 2020\end{array}$ & $\begin{array}{l}\text { ability at Muhammadiyah University, Makassar, Indonesia. } \\
\text { Approach/Methodology/Design: The descriptive qualitative research } \\
\text { method is applied in this study. The population of the research was the }\end{array}$ \\
\hline $\begin{array}{l}\text { Keywords: } \\
\text { Influence, } \\
\text { Speaking, } \\
\text { Teaching Program, } \\
\text { Pre-Service Teaching, } \\
\text { Proficiency }\end{array}$ & $\begin{array}{l}\text { students who join International Pre-service Teaching Program (P2K } \\
\text { International) at Muhammadiyah University of Makassar. Total sampling } \\
\text { technique was used. The sample consisted of fifteen students who joined in } \\
2017 \text { and thirteen students who joined in } 2018 \text {. } \\
\text { Findings: The results of the study indicate that the pre-service teaching in } \\
\text { the international program has a significant influence on the students, } \\
\text { English speaking ability at Muhammadiyah University of Makassar. The, } \\
\text { statistical analysis showed that this program improved the students, } \\
\text { speaking skills remarkably. }\end{array}$ \\
\hline Paper Ту। & $\begin{array}{l}\text { Practical Implications: The study will contribute positively to the } \\
\text { understanding of the influence of international pre-service teaching }\end{array}$ \\
\hline$\underline{\text { Rese }}$ & program. The results will provide the concerned bodies with feedback that \\
\hline $\begin{array}{l}\text { Corresponding Author: } \\
\text { Suardi }\end{array}$ & $\begin{array}{l}\text { can be used to improve the outcomes of the program. } \\
\text { Originality/value: This study explores the influences of the pre-service } \\
\text { international program at Muhammadiyah University of Makassar. It }\end{array}$ \\
\hline $\begin{array}{l}\text { Email: } \\
\text { suardialdy07@gmail.com }\end{array}$ & $\begin{array}{l}\text { provides insights into the program being employed at this university, } \\
\text { highlighting its strengths and the possible points of weakness. }\end{array}$ \\
\hline
\end{tabular}

\section{Introduction}

English as an international language is used to communicate, strengthen and fasten relationships among all countries in all fields (Ramelan, 1992, p.2). It plays an important role for specific functions, such as business, scientific innovation, and technological advancement. Because of the importance of English, special attention must be given to the English teaching and learning process in schools and colleges. In Indonesia, English has been chosen as the first-foreign language in school curriculum. It is because of a simple reason that English plays an important role in the international communication and business. It is hoped that it can be a means for acquiring science and technology. Therefore, Indonesian people study English to become skilful and ready to face both national and international challenges, engaging in the overall development of the nation. In 2000, the Directorate general of Higher Education issued a policy about higher education curriculum development based on the Decree of the Minister of National Education No. 232/U/2000. 
The Kepmendiknas National Education Regulation actually becomes no longer relevant to be used as a basis for LPTK (Educational Personnel Educational Institutions) curriculum development. In the latest development to produce graduates at each track, level and type of education, has been established by the Presidential decree No.8 of 2012 about the National Qualifications Framework Indonesia (KKNI). The substance of each course in the LPTK curriculum is adapted to the demands of contemporary urgencies to promote the re-education of character and maximize the use of ICT in learning, referring to KKNI, and to ensure the quality of future prospective professional educators. Therefore, faculty of Teacher Training and Education, Muhammadiyah University of Makassar highly regards the implementation of service learning course with special consideration to LPTK students as prospective teachers. In order to maintain relevant learning, then Muhammadiyah University of Makassar conducts re-contextualization of service learning course. To that end, the operational design is expected to meet the needs of the students and the society at large.

One form of KKN re-contextualization is to change its name to the KKN-The Consolidation of Teaching Profession (P2K). Furthermore, Muhammadiyah University of Makassar made cooperation with University of technology Malaysia (UTM) to conduct The Consolidation of Teaching Profession (P2K) in an international scale. Since 2014 until today, Muhammadiyah University of Makassar had been involved in several academic activities to improve the quality of prospective teachers by sending its students to join this program. The International Consolidation of Teaching Profession (P2K International) serves as a training ground for students to apply a range of knowledge, attitudes, and skills in the context of the formation of a professional teacher.

Muhammadiyah University of Makassar and UTM have established a very close relationship so that Pre-service Teaching International Program (P2K International) had become a very important activity for students to gain valuable experience which they will assist them in dealing with multilingual students. Due to this program, the students gain considerable experiences especially in English Speaking skills. As a future teacher, they are expected to have good communication skills.

From the explanation above, the present study aims to investigate the influence of Pre-service Teaching in the International Program (P2K) on students' speaking English ability at Muhammadiyah University of Makassar.

\section{Methodology and Procedures}

In this research study, the descriptive method is used in analyzing the data. The descriptive method is a method employed to describe everything related to the topic of the research since it uses to analyze the data descriptively, not in the form of percentage or numerals (Sutopo, 2002, p.7). The variable of this research was English speaking ability, while grammar, self confidence, fluency, and vocabulary were selected to be the indicators of this research. The population of this research was the students who joined International Pre-service Teaching Program (P2K International) at Muhammadiyah University of Makassar. There were twenty eight students, fifteen of which joined in 2017 (first group) and thirteen students joined in 2018 (second group). 
Table 1: Total Sample

\begin{tabular}{|c|c|c|}
\hline No. & Year & Total Students \\
\hline 1. & 2017 & 15 Students \\
\hline 2. & 2017 & 13 Students \\
\hline \multicolumn{2}{|c|}{ Total } & 28 Students \\
\hline
\end{tabular}

Source: Darmasiswa and International Affairs Administrator

The sample includes twenty eight students selected as participants in this research. Total sampling technique is used in this research. For collecting data, the researchers used questionnaire and interview as instrument. The questionnaire consists of a list of 10 statements ( 5 positive and 5 negative). The researchers distributed the questionnaire to the students to respond to a series of statements by indicating whether one Strongly Agree (SA), Agree (A), Undecided (UN), Disagree (D), or Strongly Disagree (SD) with each statement. Each response is associated with a point value and individual's score which is determine by summing with a point value of each statements. The point value will be assigned to response the positive statements and negative statements.

Table 2: Likert Scale

\begin{tabular}{|c|c|c|c|c|c|}
\hline Items & SA & A & UN & D & SD \\
\hline Positive statements & 5 & 4 & 3 & 2 & 1 \\
\hline Negative statements & 1 & 2 & 3 & 4 & 5 \\
\hline
\end{tabular}

Source: (Azwar, 1995, p.140)

\section{Results and Discussion}

The data collected in this research is analyzed by using the procedures as it follows:

Scoring the correct answer of pre-test and post-test

$$
\text { Students Score }=\frac{\text { The Number of Student's Correct Answer }}{\text { Total Score }} \times 100
$$

The result of the percentages of the students score was tabulated and classified as the following classification

$\begin{array}{ll}96-100 & \text { is classified as excellent } \\ 86-95 & \text { is classified as very good } \\ 76-85 & \text { is classified as good } \\ 66-75 & \text { is classified as fairy good } \\ 56-65 & \text { is classified as fair } \\ 36-55 & \text { is classified as poor } \\ 0-35 & \text { is classified as very poor }\end{array}$

(Depdikbud, 1997, p.19).

Calculating the collected data from the students in answering the test, the researchers used the formula below to get mean score: 


$$
\bar{X}=\frac{\sum x}{N}
$$

Where :

$$
\begin{aligned}
& \bar{X}=\text { Mean Score } \\
& \sum \mathrm{X} \quad=\text { The sum of all scores } \\
& \mathrm{N} \quad=\text { The total number of sample }
\end{aligned}
$$

(Gay, 1981, p. 298).

The analysis of the data is presented under two headings; data collected through questionnaire, and the data collected through interview.

\section{The Data through Questionnaire}

The researchers administered the questionnaire to the respondents and only twelve respondents were willing to participate in this research. The researchers gathered the data from the questionnaire with twelve statements, six positive statements and six negative

\begin{tabular}{|c|c|c|c|}
\hline \multirow{2}{*}{\multicolumn{2}{|c|}{$\begin{array}{c}\text { Types of } \\
\text { Statements }\end{array}$}} & \multicolumn{2}{|c|}{ Score Of The Response Categories } \\
\hline & & Calculating the score of statements & Score \\
\hline \multirow{6}{*}{$\begin{array}{l}\mathbf{P} \\
\mathbf{O} \\
\mathbf{S} \\
\mathbf{I} \\
\mathbf{T} \\
\mathbf{I} \\
\mathbf{V} \\
\mathbf{E}\end{array}$} & SA & $12 \times 5$ & 60 \\
\hline & A & $22 \times 4$ & 88 \\
\hline & UN & $22 \times 3$ & 66 \\
\hline & $\mathrm{D}$ & $7 \times 2$ & 14 \\
\hline & SD & $9 \times 1$ & 9 \\
\hline & \multicolumn{2}{|r|}{ T O T A L } & 237 \\
\hline \multirow{6}{*}{$\begin{array}{l}\mathbf{N} \\
\mathbf{E} \\
\mathbf{G} \\
\mathbf{A} \\
\mathbf{T} \\
\mathbf{I} \\
\mathbf{V} \\
\mathbf{E}\end{array}$} & SA & $4 \times 1$ & 4 \\
\hline & $\mathrm{S}$ & $13 \times 2$ & 26 \\
\hline & UN & $18 \times 3$ & 54 \\
\hline & $\mathrm{D}$ & $15 \times 4$ & 60 \\
\hline & SD & $22 \times 5$ & 110 \\
\hline & \multicolumn{2}{|r|}{ TO T A L } & 254 \\
\hline
\end{tabular}
statements. Based on the data analysis, the total scores of each of the response categories are shown in the table 3 as it follows:

Table 3: Data obtained through questionnaire

Source: Authors 
Table 5: The Total Scores

\begin{tabular}{l|c|c}
\hline Response Categories & Positive Statement & Negative Statement \\
\hline Strongly Agree & 60 & 4 \\
Agree & 88 & 26 \\
Undecided & 66 & 54 \\
Disagree & 14 & 60 \\
Strongly Disagree & 9 & 110 \\
\hline
\end{tabular}

Source: Authors

The table above shows that 60 of the participants score "Strongly Agree", and eighty eight of them score "Agree". As indicated, 66 of the sample chose "Undecided", 14 of them chose "Disagree" and 9 of them scored "Strongly Disagree" in positive statements. Besides, in negative statement it shows that 4 scores "Strongly Agree", 26 scores Agree, 54 scores Undecided, 60 scores Disagree and 110 scores "Strongly Disagree" in negative statements.

Furthermore, from the total scores stated above, the mean scores of each of the response categories are shown in table 4.3 as follows:

Table 6: The Mean Scores

\begin{tabular}{l|c|c}
\hline Response Categories & Positive Statement & Negative Statement \\
\hline Strongly Agree & 10 & 0.67 \\
Agree & 14.67 & 4.33 \\
Undecided & 11 & 9 \\
Disagree & 2.33 & 10 \\
Strongly Disagree & 1.5 & 18.33 \\
\hline
\end{tabular}

Source: Authors

Finally, the percentages of response for each category are presented in the table below.

Table 7: The Mean Scores

\begin{tabular}{l|c|c}
\hline Response Categories & Positive Statement & Negative Statement \\
\hline Strongly Agree & 25.31 & 1.57 \\
Agree & 37.14 & 10.24 \\
Undecided & 27.85 & 21.26 \\
Disagree & 5.90 & 23.63 \\
Strongly Disagree & 3.80 & 43.30 \\
\hline T o t a l & $100 \%$ & $100 \%$ \\
\hline
\end{tabular}

Source: Authors 


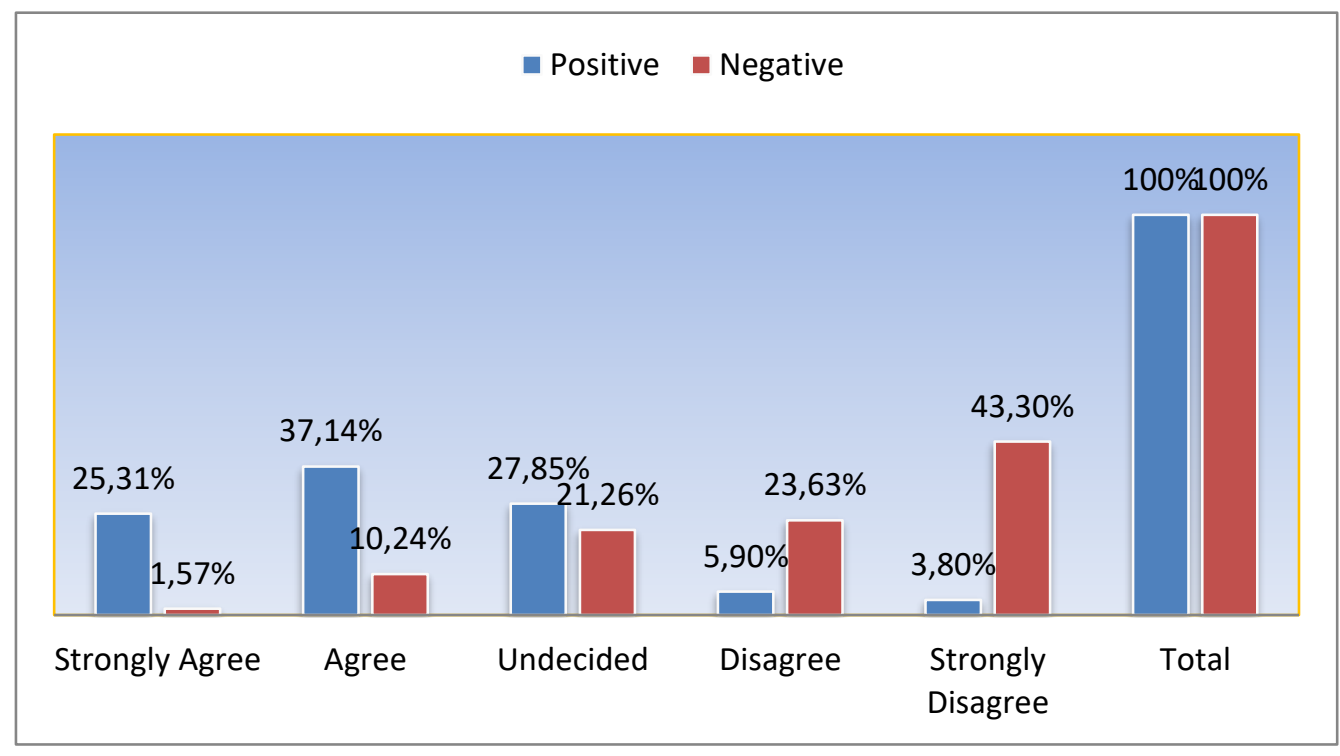

Figure 1: Percentage distribution to negative and positive statements

The figure above shows that there were $25.31 \%$ students chose Strongly Agree from 237 items in positive statement and 37.14\% Agree, 27.85\% Undecided, 5.90\% Disagree, and then $3.80 \%$ students chose Strongly Agree. While 1.57\% students chose Strongly Agree from 254 items in negative statement and 10.24\% Agree, 21.26\% Undecided, 23.63\% Disagree, and then $43.30 \%$ students chose Strongly Agree. Based on the data analysis, it is concluded that the speaking abilities of the students joining Pre-service Training International Program at Muhammadiyah University of Makassar are varied. Furthermore, before joining the Preservice Training International Program, some of them rarely used English in daily activities and they had no not command of grammar.

\section{The Data through Interview}

For question no.1 'how did you feel after joining the Pre-service Teaching International Program?' most of the students reported that they really feel different while back to home country. 'I enjoy the process there' said students. There other students reflected that they miss their pupils in Malaysia.

For question number 2 'How is the learning process there?', 10 students said that they need to learn and adjust with the learning process in Malaysia. Even though they have read and prepared themselves before going to Malaysia, they still need time and little bit effort to blend with the learning process there. Two students said that they feel thankful for Muhammadiyah University of Makassar for giving them the required information before joining Pre-service Teaching International Program. For question number 3 'How did you feel about your speaking ability after joining the program?', all the students indicated that considerable improvement is realized in their speaking ability. They can feel it after arrival back to home country.

For question number 4 'How is your feeling about your confidence after joining the program?', all the students expressed the same point of view that there is significant boost in their confidence after joining the Pre-service Teaching International Program. For question number 5 'did you learn grammar while going abroad?', only five students said that they 
were learning grammar during the Pre-service Teaching International Program. They learnt while they were teaching in classroom in Malaysia. For question number 6 'how is your vocabulary after the program?', all the students revealed that Pre-service Teaching International Program enriched their vocabulary both in English and Melayu. For question number 7 'did you feel any improvement in your speaking ability after joining Pre-service Teaching International Program?', all of the students indicated that joining the program improved their speaking ability in all aspects.

\section{Before Joining the Pre-service Teaching International Program}

The discussion about 'how was students' English speaking ability before joining the Preservice Teaching International Program' can be analyzed by the results the questionnaire. For item number 1 the statement is 'I am really confidence to communicate using English'. This statement aimed to know the students' situation before join Pre-service Teaching International Program and as we seen in finding as a result 3 students feel doubt and do not know about their confidence. It means that the students have little bit confidence before join Pre-service Teaching International Program.

For item number 2 the statement is 'I always use English in daily conversation'. This statement aimed to identify whether the students use English as their main language before Pre-service Teaching International Program. By examining the findings, it can be seen that eight students or most of the students did not use English as their main language. For item number 3, the statement is 'I have taken English course before join Pre-service Teaching International Program'. This statement shows which students took English course before join Pre-service Teaching International Program. As the result shows we know that there are 4 students having no English course before joining Pre-service Teaching International Program and there are 8 students who had a course in English before joining the program. It means that students' English speaking ability are varied and most of them need to learn English before joining the Pre-service Teaching International Program because they feel not satisfied with their English.

For item number 4, the statement is 'I am from English department'. This statement gives information about the study track of the students. Students of English departments have a good command of basics in English than the students who are not from English department. The responses to the questionnaire indicate that half of the respondents are from English department and the rest are from other departments. It means that half of the students are not used to learning with English as a medium of instruction. For item number 5, the statement is 'I can communicate with English fluently. The statement is meant to identify whether they speak fluently or not. Based on analysis, almost all of the respondents are not fluent in English before joining Pre-service Teaching International Program.

For item number 6, the statement is 'I am really good at English grammar'. This statement gives information whether the student has good English or not before joining the Pre-service Teaching International Program. The responses indicate that the students' knowledge of grammar was not good enough. For item number 7 the statement is 'I have no self confidence to communicate using English'. This statement is negative implying whether they have 
confidence in public speaking using English or not. The results reveal that 6 students from 12 respondents state that they have no self confidence to communicate using English. For item number 8, the statement is 'I rarely use English in daily activity'. This item aimed to identify whether the students always use English in their daily conversation or not. The data analysis reveals that 12 students indicated that they do not use English in their daily conversation. It means that before joining the Pre-service Teaching International Program, they were not using English for conversation. For item number 9, the statement is 'I never take English course before join Pre-service Teaching International Program'. This statement gives information about students whether they took English course before join Pre-service Teaching International Program or not. The result previously shows that most students took course before join Pre-service Teaching International Program. It implies that they still learn how to speak in English.

For item number 10, the statement is 'I am not from English department'. The statement aimed to find out neither the students are from English department or not. People believe that the students from English department have a good basic in English than the students who are not from English department. By looking at the results, it tells us that 4 over 12 students are not from English department. It means that some students are not having a good basic in English before Pre-service Teaching International Program. For item number 11, the statement is 'I cannot communicate with English fluently'. This statement measures the students' speaking ability at fluently level or not. The analysis of the responses shows that four students cannot communicate in English fluently. It means that the students' situation before Pre-service Teaching International Program they still not fluently to speak using English, even though they can speak but it is little by little before.

For item number 12, the statement is 'I am not good in English grammar'. This statement identifies the students' command of grammar. The data analysis shows that there were 8 students reporting that they are not good at grammar. It means almost all students had no adequate knowledge of English grammar while they are speaking. Hence, it is concluded that before joining the Pre-service Teaching International Program, most of the students can speak in English even though they have little confidence to speak in public. This lack of confidence is attributed to their infrequent use of English in daily conversation. Furthermore, their command of structure was not adequate. Consequently, they had to take English course before joining the program.

\section{After Joining Pre-service Teaching International Program}

The students indicated that they were satisfied for their participation in the program. Their most remarkable evaluation is that experience enriched and language skills improved. Almost all the students had the same point of view that Pre-service Teaching International Program made a difference in their preparation as prospective teachers. The question about learning process while having Pre-service Teaching International Program, the students indicated that they had to exert effort to adjust and learn.

The teaching/learning process in Malaysia is one of the greatest advantages for the respondents to learn from. They had good exposure to a different educational system, and 
their interaction with the program facilitators equipped them with new insights in teaching as a profession. They had to realize what they are teaching; mastering the topic before delivering it to the students. In terms of adjustment, the respondents needed some time to and effort to blend and get used to the learning process and the new environment in Malaysia.

Mastering communication skills is one way towards the success of Pre-service Teaching International Program. Even in the teaching process, a good teacher is the one who masters communication and knows how to deliver their knowledge to the students. Confidence is also an important factor in improving speaking skills. All respondents have the same of view about it. By joining Pre-service Teaching International Program all respondents said that their self-confidence after the program significantly improved and they feel no worry anymore to speak in public. This change will definitely enhance their profession as teachers.

In terms of grammar, the students indicated that they had no full mastery of the grammatical structures. However, they considered it as a continuous learning process. During the Preservice Teaching International Program, the students enriched their vocabulary. This aspect influence the students' speaking ability after the program. Most importantly, all the respondents believe that after joining Pre-service Teaching International Program, their English speaking ability significantly improved in all aspects.

From the results and discussions of this research, the researchers concluded that all students benefited from joining the Pre-service Teaching International Program. Their self-confidence improved and their hesitation in speaking in public declined. In terms of grammar, they cannot deny that their grammar become well. Their vocabulary capacity was significantly enriched after the program. All these aspects lead the students to become speaker especially in English. Furthermore, these findings indicate that Pre-service teaching international program has significantly influenced to the students' English speaking ability at Muhammadiyah University of Makassar.

\section{Conclusion and Suggestion}

Based on the research findings, before joining Pre-service Teaching International Program, most of the students had no mastery of speaking skill due to lack of confidence and practice in daily conversation. Joining the program resulted in improvement of the students' speaking skills, vocabulary, and grammar. Their exposure to a different educational system enriched their experiences as prospective teachers. In addition, students' interaction and participation in teaching equipped them with the necessary teaching skills. It is concluded that the Preservice Teaching International Program has significantly influenced and improved the students' English speaking ability at Muhammadiyah University of Makassar.

\section{Conflict of Interest}

The author of this research article declares no conflict of interest. 


\section{Funding}

This research study was not funded by any institution. The author conducted the study on his own expenses.

\section{References}

Azwar, Saifuddin. (1995). Human Attitude Theory and Measurement. Yogyakarta : Pustaka Pelajar

Ba'dulu, Abdul Muis. (2009). Advanced English grammar. Makassar: Badan Penerbit UNM

Brown, H. D. (2000). Principles of language learning and teaching (Vol. 4). New York: Longman.

Channey.M.(1998). Teaching English to Speakers of Other Language. London: Cambridge University Press

Cooper, J. (1991). Sabotaging cooperative learning: Or, snatching defeat from the jaws of victory.. Cooperative Learning and College Teaching.

Depdikbud. 1985. Petunjuk Pelaksanaan Proses Belajar Mengajar dan Petunjuk Pelaksanaan Sistem Penilaian. Jakarta: Depdikbud

Ministry of Education and Culture. (1985). Instructions for the Implementation of the Teaching and Learning Process and the Implementation Guidelines for the Assessment System. Jakarta.

Depdikbud. 1997. Petunjuk teknis pengajaran Bahasa Inggris. Jakarta : Depdikbud

Gay, L.R . (2006). Educational research: competencies for analysis and applications. Upper Saddle River, NJ : Pearson Merrill Prentice Hall.

Hirai, Ritzuko. (2010). Handbook of The First Year ESL Students in University. New York: Pearson Education Inc.

Malayanti.(2004). The Comparison between Students' English Speaking Achievement living at and out of dormitory at As'adiyah Islamic Boarding School Sengkang Wajo Regency. Thesis UIN

Ramelan. 1992. Introduction to Linguistic Analysis. Semarang : IKIP Semarang Press

Samad, Yassin. (1989). The Speaking Ability of The Third Semester Students of English Department of FPBS IKIP Ujung Pandang. Thesis UNM.

Suryabrata.(2000), Aspects of Language Teaching. Oxford: Oxford University Press

Sutopo, H.B. (2002). Qualitative Research Methodology.Surakarta : Sebelas Maret University Press.

Syamsuri, Sukri.DKK.2015.Instruction Book Pre-Service Teaching Program (P2K). Makassar. FKIP Universsitas Muhammadiyah Makassar 